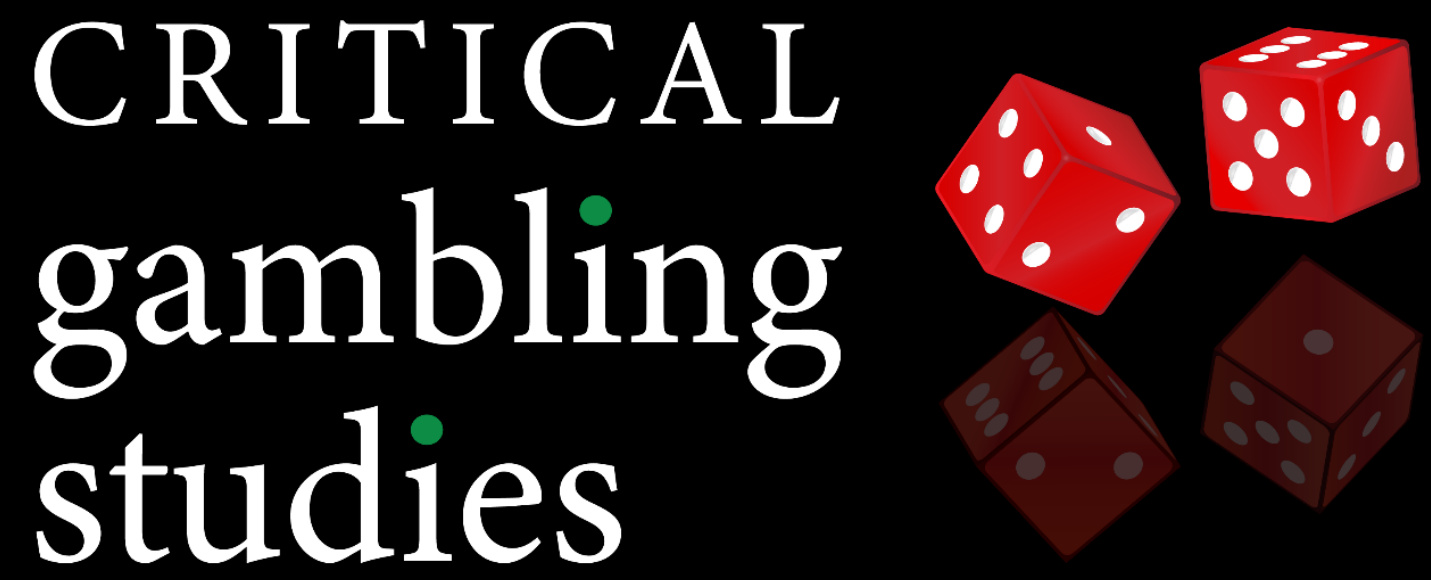

ISSN: 2563-190X. Available Open Access at https://criticalgamblingstudies.com

\title{
Tribal Casino Labor Relations and Settler Colonialism
}

Theodor P. Gordon

APA Citation: Gordon, T. (2021). Tribal Casino Labor Relations and Settler Colonialism. Critical Gambling Studies, 2(2), 151-158. https://doi.org/10.29173/cgs73

Article History:

Received August 2020

Accepted July 2021

Published September 2021 


\title{
Critical Gambling Studies (2021)
}

Vol. 2, No. 2

Critical Indigenous Gambling Studies

\section{Tribal Casino Labor Relations and Settler Colonialism}

\author{
Theodor P. Gordon ${ }^{a^{*}}$
}

${ }^{\text {a }}$ College of St. Benedict and St. John's University

\begin{abstract}
Sovereignty provides the legal basis for tribal casinos in the United States. However, since the industry's rapid growth (valued at $\$ 34$ billion for 2019), courts are now revisiting decades-old precedents in federal Indian law to reinterpret policies in ways that add new constraints to tribal sovereignty. Because tribal casinos often employ large numbers of non-Native Americans, tribal casino labor relations have become a new arena for contests over the boundaries of tribal sovereignty. This article investigates recent tribal casino labor relations court rulings (e.g., Little River, Soaring Eagle, and Pauma) through the lens of settler colonialism in order to understand new revisions to legal precedents. It argues that settler colonialism continues to underlie federal policies and that the growth of tribal casinos reveal that the federal government may intervene to undercut tribal sovereignty.
\end{abstract}

Keywords: labor relations, tribal sovereignty

\section{Introduction}

In 2007, the United States D.C. Circuit Court of Appeals decided San Manuel v NLRB, (341 NLRB 1055), overturning a longstanding legal precedent on the right of tribal governments to govern labor relations with their employees. More than a decade later, tribal governments continue working to mitigate the fallout of San Manuel, including efforts to advance a bill through the United States Congress to undo San Manuel. Why do many tribal governments consider overturning San Manuel to be central to preserving their sovereignty? The answer lies in the successes of the tribal casino industry (now valued at over $\$ 30$ billion) and concerns that these successes motivated the federal government to renew its pursuit of settler colonialism, the displacement of Indigenous peoples from their land (Wolfe, 1999). This article examines the fallout from San Manuel to show that a seemingly niche issue-laws governing tribal casino labor relations-is fundamentally tied to longstanding fights for both tribal sovereignty and organized labor. Through this investigation, one can see how features of the United States' political system, including the structure of federal courts and partisanship in the United States Congress, make it possible for settler colonialism to be advanced even by those who explicitly reject it.

From the modest beginnings of tribal gaming in the late 1970s, Unites States federal and state government responses have ranged from outright resistance to conditional acceptance. Even at its most supportive of tribal gaming, federal and state policies demand concessions from tribal governments. Cattelino (2010, p. 235) identified tribal casinos as caught in a double bind, where "American Indian tribal nations (like other polities) require economic resources to exercise sovereignty, and their revenues often derives from their governmental rights; however, once they exercise economic power, the legitimacy of tribal sovereignty and citizenship is challenged". As a settler society built on Indigenous land, the United States' tenuous recognition of tribal sovereignty was achieved only as result of centuries of Native activists working to secure their rights. Gordon (2018) demonstrates how their experiences of colonization gave Native activists the knowledge necessary to effectively challenge colonial policies and substantially revitalize their sovereignty, most visibly through the tribal casino movement. If settler colonialism shapes federal policies, then one would expect the spaces where tribes make the greatest gains would become the sites where the federal government pushes back the strongest. Kamper (2010) argues this is exactly what federal courts did in San Manuel. He provides a thoughtful analysis of the San Manuel decisions wherein federal courts cited the successes of tribal gaming as rationale for reversing a decades-old legal precedent that had acknowledged

\footnotetext{
${ }^{*}$ Corresponding author. Email: tgordon@csbsju.edu
} 
tribal governments' sovereignty over labor relations with their employees. Because the most financially successful tribal casinos rely on labor forces that are majority non-Native, they create a novel work environment, where non-Native employees commute to Indian reservations to serve tribal government enterprises. In his groundbreaking book, The Work of Sovereignty (2010), David Kamper argues that court decisions governing tribal labor relations can provide a barometer for determining when the federal government signals that it will push back against the achievements of tribal governments. He asked readers to "stay tuned" to whether other courts continued to uphold this revision or if the United States Congress would intervene (2010, p. 67).

Since the San Manuel decisions, we now have a much clearer view of where courts and policymakers are headed. This article examines three court cases (NLRB $v$ Soaring Eagle [2015], NLRB v Little River [2015], and Pauma $v$ NLRB [2018]) and the failed Tribal Labor Sovereignty Act (TLSA) to demonstrate how tribal casino labor relations remain an arena in which tribal governments and the United States continue to grapple over the boundaries of tribal sovereignty. In effect, these developments represent a continuation of settler colonialism. However, an examination of the courts' opinions and congressional testimony on the TLSA reveal that many of the judges and policymakers who curtailed tribal efforts to overturn San Manuel do not publicly support the settler colonial agenda of displacing tribal sovereignty. Instead the structure of appeals court panels and high levels of congressional partisanship, combined to undercut tribal governments' attempts to mitigate San Manuel.

\section{Tribal Corporations and Labor Relations}

To understand the significance of the San Manuel court decisions and why tribal governments perceive them as a threat to sovereignty, one must first understand the broader context of tribal corporations and labor relations. In 1934, Congress passed the Indian Reorganization Act (IRA), which created a system by which the federal government would recognize tribal governments, but only if tribes adopted constitutions with key provisions written by the federal government. While the IRA limited the political structures that tribal governments could adopt, it broadly recognized tribal governments' right to own property of all types. Section 17 of the IRA provides that, "[a tribal government] charter may convey to the incorporated tribe the power to purchase...or otherwise own...property of every description....and such further powers as may be incidental to the conduct of corporate business". With the IRA, the federal government recognized that Native nations can hold any kind of property, including corporations. Congress's intention was clear, to recognize that property ownership is a key part of sovereignty and is necessary for Native nations to provide for their communities. Policymakers may not have envisioned that one day tribes would operate casinos, but Section 17 made possible the tribal ownership of any kind of corporation, setting the stage for tribal casinos.

The following year Congress passed the National Labor Relations Act of 1938 (NLRA), which established regulations for labor relations in the private sector. It created the National Labor Relations Board (NLRB) to adjudicate decisions in applying the NLRA. Section 2(2) of the NLRA states that the employers it applies to "...shall not include the United States or any wholly owned Government corporation...or any State or political subdivision thereof...". The federal and state governments have their own labor relations policies and the NLRA does not apply to them. The text of the NLRA does not specifically mention tribal governments, so are they exempted like federal and state governments? In a 1960 ruling (Federal Power Commission v. Tuscarora Indian Nation, 1960), the United States Supreme Court decided that in cases where a law does not specifically mention tribal governments, it can only be applied if Congress intended the law to apply to all Americans and if it does not interfere with tribal sovereignty. Based on the Tuscarora decision, in 1976 the NLRB ruled that the NLRA does not apply to tribal governments. In this case (Fort Apache Timber Co. 226 NLRB 503) the White Mountain Apache Tribe owned a timber company that operated entirely on tribal land. The NLRB ruled that the NLRA does not apply in such circumstances because the company is tribally owned, and Congress did not intend for the NLRA to interfere with tribal governments. For decades, it appeared to be clear: if a tribal government owns a corporation that operates on tribal land, then it is a government employer and the NLRA does not apply. However, the emergence of tribal casinos proved to be a turning point not just for tribal economic development but also for courts to revisit this precedent and to reconfigure the boundaries of tribal sovereignty.

Beginning in the late 1970s, tribal governments across the United States began experimenting with bingo and poker operations as a potential venue for raising much needed revenue. In each case, the operation was an expression of the tribe's sovereignty, with tribal governments passing the legislation and regulations necessary to support their citizens. A few, like the Seminole Tribe of Florida, faced legal challenges and won (Seminole Tribe of Florida v Butterworth, 1981). In 1980, The Cabazon Band of Mission Indians opened their poker club on their reservation in the desert of Southern California and faced nearly a decade of legal challenges before succeeding in the landmark Supreme Court case Cabazon v California. In brief, the Supreme Court acknowledged that Cabazon, as a federally recognized Native nation, has the jurisdiction to regulate any activity that is legalized and regulated by its surrounding state, California (see Gordon, 2018; Lane, 1995; and Rossum, 2011 for a more detailed background on the case). Because California had 
previously legalized and regulated gambling, Cabazon could too. The Cabazon decision secured that tribal governments across the United States could chose to legalize and operate gambling establishments on their reservations.

Congress soon intervened with the Indian Gaming Regulatory Act of 1988 (IGRA), which demarcated gambling into three classes, each with its own levels of oversight. Under IGRA, Class 3 includes most lucrative forms of gaming, including games that are backed by the house, like slot machines and blackjack. IGRA mandates that if tribal governments want to pursue Class 3 gambling, they must first negotiate a compacta legally binding agreement-with the surrounding state that grants the state regulatory oversight. The terms of compacts vary widely from state to state. In California's tribal gaming compacts, the state required tribal governments to pass Tribal Labor Relations Ordinances (TLROs), to regulate labor relations with tribal employees, including tribal casino employees. Under California's compacts, these TRLOs must include certain features similar to the NLRA, like the ability for employees to use cards checks to demonstrate interest in organizing a union. But there are also key differences between California's TRLO's and the NLRA (Kamper, 2010, p. 80). The case that led the NLRB to overturn the Fort Apache Timber Co. precedent began when one California Native nation, the San Manuel Band of Mission Indians, followed every aspect of the TLRO mandated by its compact. But San Manuel ran askew of the NLRA, which given the established legal precedent, they did not believe applied to their casino.

\section{The San Manuel Decision}

Located near San Bernardino, California, The San Manuel Band of Mission Indians welcomed its employees to form unions and pursue collective bargaining. When the Communications Workers of America (CWA) began organizing San Manuel's employees, the tribe granted the union access for organizing. At the same time, another union, Hotel and Restaurant Employees (HERE) also sought to organize San Manuel's employees. Prior to its attempt to organize San Manuel employees, HERE had a complicated relationship with tribal governments located in California. When tribes first attempted to negotiate compacts with California, the state resisted negotiating in good faith. Tribes then collected enough signatures to successfully petition for tribal gaming compacts to become subject to a ballot measure. HERE opposed the ballot measure and was one of the biggest sponsors against it in what became the most expensive referendum campaign in United States history (Gordon, 2000). As one of the largest unions of Las Vegas employees, HERE had a financial interest in preventing the expansion of gambling to California. After its unsuccessful attempt to block tribal gaming compacts in California, HERE then sought to organize California's tribal casino employees. While San Manuel had welcomed CWA, the tribe had a different approach to HERE. San Manuel's TLRO did not prohibit management from giving preferential treatment to one union over another. The NLRA does prohibit preferential treatment. Because of the precedent set in Fort Apache Timber Co., San Manuel did not believe the NLRA applied to their casino employees. HERE believed it did and filed a complaint with the NLRB, asserting that under the NLRA San Manuel had engaged in an unfair labor practice.

San Manuel attempted to dismiss the case, asserting that the NLRB did not have jurisdiction because under its own precedent, the NLRA did not apply. In its 2004 decision (341 NLRB 1055), the NLRB overturned the precedent set in Fort Apache Timber Co. The majority opinion decided that Congress did in fact intend for the NLRA to apply to corporations owned by tribes. Most concerning to tribal governments was that the NLRB developed a new standard for determining when it has jurisdiction over tribal enterprises. According to this new standard, the NLRB has less interest in effectuating the policies of the (NLRA) when tribal governments are pursuing "traditionally tribal or governmental functions" (p. 8) and more interest in tribal commercial activities. In this case, the Board found that "the tribe's operation of the casino is not an exercise of selfgovernance...Apart from its ownership and location, the casino is a typical commercial enterprise operating in, and substantially affecting, interstate commerce" (p. 9). Because of this new standard, the NLRB's ruling has implications well beyond tribal casino labor relations. It reframed tribal sovereignty as confined only to what the NLRB deems as "intramural" or internal activities that only affect tribal members. In other words, the new standard established that the moment a tribal government is engaging in an activity that affects nonmembers, it forfeits its sovereignty on that activity, creating the type of double bind identified by Cattelino (2010).

San Manuel appealed to the D.C. Circuit Court, which sided with the NLRB's decision (San Manuel $v$ NLRB, 2007). In its ruling, the appeals court declared that the NLRA should apply because "The total impact on tribal sovereignty at issue here amounts to some unpredictable, but probably modest, effect on tribal revenue and the displacement of legislative and executive authority that is secondary to a commercial undertaking" (p. 8). The D.C. Circuit Court's ruling created the possibility that San Manuel's case could undermine tribal sovereignty in spheres well beyond tribal casino labor relations. Specifically, the D.C. circuit asserted that constraints could apply to San Manuel and other tribes because, "First the operation of a casino is not a traditional attribute of self-government" and "Second, the vast majority of the Casino's employees and customers are not members of the Tribe..." (p. 8). Thus, tribal sovereignty does not extend to any tribal pursuits that are not what the court perceives as a traditional activity of a government or that impact individuals who are not members of that government. 
Kamper's (2010, p. 83) analysis of the San Manuel case astutely argues that the court's application of "traditional" is arbitrary and that federal and state governments routinely engage in activities that blur the line between government and commercial. The most obvious example is that many state governments directly operate gambling facilities. Likewise, all state governments engage in activities that impact the citizens of other states. In reflecting on the court's decision, gaming law professor Nelson Rose wrote that, "Tribes had near absolute sovereignty as long as they were living in poverty, isolated from the rest of American society. No one cared until they gained economic and political power. Now it might all be taken away" (Rose, 2006, p. 60). The San Manuel decision created a double bind where courts may recognize tribal governments to enact their own "intramural" sovereignty, but limit their sovereignty the moment the tribal government engages in the wider economy, even though all governments need to engage with the broader economy to sustain themselves. While the San Manuel decisions set a new precedent, it was not immediately clear if other courts would follow the lead of the DC circuit. Now, recent decisions show exactly where courts are headed and illustrate the challenges tribal governments face in reversing the impacts of San Manuel.

\section{Little River, Soaring Eagle, and Pauma}

San Manuel never appealed the D.C. Circuit Court's decision, so the case never went to the Supreme Court and other circuit courts were not bound by D.C.'s decision. To measure San Manuel's impact, one must look to whether other circuit courts would choose to apply it. The first test came in 2015 when two Michiganbased tribal casino labor relations cases came before the 6th Circuit Court of Appeals. The 6th Circuit Court heard both NLRB v Little River (2015) and NLRB v Soaring Eagle (2015) concurrently and issued rulings within 3 weeks of each other. Between the two cases, all six judges on the 6th Circuit weighed in on the cases, with each case being assigned a panel of three judges. Of the court's six judges, four argued that the NLRA should not apply to tribal government enterprises, like casinos. However, despite four of six judges opposing the NLRB's jurisdiction, the court ruled against the tribes in both cases. Examining how the court ended up ruling against a position that the majority supported reveals that settler colonialism played a role but was not the predominant factor in the $6^{\text {th }}$ Circuit Court's application of San Manuel.

In the first case, The Little River Band of Ottawa Indians passed a Fair Employment Practices Code (equivalent to a TLRO) that included regulations on labor-organizing activities. Following the San Manuel decisions, the NLRB ordered Little River to cease enforcing any of the aspects of its TLRO that conflict with the NLRA. The Little River Band appealed to the 6th Circuit, which asserted that, "a federal statute creating a comprehensive regulatory scheme presumptively applies to Indian tribes" (p. 16). In other words, while the Supreme Court's 1960 Tuscarora decision declared that a federal law can only apply to tribal governments if Congress intended it to, because the Little River panel of the $6^{\text {th }}$ Circuit Court saw the NLRA as a "comprehensive regulatory scheme" (p. 16), it presumed that Congress must have intended it to apply to tribal governments. In its 2-1 decision against Little River, the panel expanded Tuscarora to include all federal laws that could, presumably, be construed as applying tribal governments, even if Congress never expressed that intent.

This decision advanced settler colonialism because it reinterpreted a longstanding legal precedent to diminish the sovereignty of tribal governments over their own territory. Like the San Manuel decisions, Little River reaches well beyond the realm of tribal casino labor relations. Previously under Tuscarora, if Congress did not specify that it intended a law to apply to tribal governments or to be generally applicable across the country, it did not apply to tribal governments. But Little River flipped this interpretation. Now, if Congress did not express intent on whether a law should apply to a tribal government, the court will presume that it does apply. Little River supplants federal for tribal authority on a wider range of matters, well beyond tribal labor relations. However, what came next, with Soaring Eagle, exposed that most of the 6th Circuit Court opposed the new precedent but was now powerless to stop it.

The Soaring Eagle Casino and Resort is owned and operated by the Saginaw Chippewa Tribe of Michigan, which established a no-solicitation policy for employees that prevents them from soliciting and posting materials at work. In 2010, casino management terminated a housekeeper who, after several warnings, continued to promote union-organizing with coworkers. The fired employee filed an unfair labor practices complaint under the NLRA, which prohibits employers from retaliating against employees who discuss unionization. The NLRB applied the new precedent set by the San Manuel decisions and ruled in favor of the complainant. Soaring Eagle appealed to the 6th Circuit Court, which heard the case concurrently with the Little River Band case, though with a separate panel of three judges. In its decision, the Soaring Eagle panel argued that the NLRA should not apply because

1) the fact that the Casino is on trust land and is considered a unit of the Tribe's government; (2) the importance of the Casino to tribal governance and its ability to provide member services; and (3) the [complainant] (and other nonmembers) voluntarily entered into an employment relationship with the Tribe. (p. 26)

Notwithstanding its arguments against applying the NLRA, all three judges on the panel voted that it must apply because they were bound by the Little River 
decision, which was decided only three weeks earlier. In concluding its opinion, the Soaring Eagle panel wrote, "For all of these reasons, if writing on a clean slate, we would conclude that... the Tribe has an inherent sovereign right to control the terms of employment with nonmember employees at the Casino, a purely tribal enterprise located on trust land" (p. 27). Because the Soaring Eagle decision specifically acknowledges the sovereignty of tribal governments over labor relations, it counters the settler colonial stance taken by Little River, despite being powerless to change it. Given that the 6th Circuit heard Soaring Eagle and Little River concurrently by separate panels, whichever panel concluded the case first would establish the court's precedent. If the timing or make-up of the panels were slightly different, the court could have ruled in favor of the tribes.

Both Little River and Soaring Eagle appealed to the Supreme Court. However, the Supreme Court declined to hear their cases, letting the 6th Circuit rulings stand. Since the 6th Circuit rulings, the impact of the San Manuel decisions continues to spread. In 2018, the 9th Circuit Court supported the NLRB's application of San Manuel to labor relations at the Pauma Casino (Casino Pauma v NLRB, 21-CA-125450). In 2019, the Supreme Court also declined to hear Pauma's appeal. It now appears that the shifting scope of federal constraints on tribal casino labor relations has settled. The new precedent now stands without any apparent avenue to be challenged through the courts. Tribal governments are now charting a new path through the United States Congress to protect their sovereignty over such matters. Many are now advocating for the Tribal Labor Sovereignty Act (TLSA), which would provide a simple amendment to the NLRA. But in passing Congress, the TLSA is facing partisan headwinds.

\section{Tribal Labor Sovereignty Act}

The cases outlined above all center on Section 2(2) of the NLRA's definition of employer, which exempts federal and state governments but does not mention tribal governments. First introduced in 2015, the TLSA would provide a short amendment to the NLRA to explicitly add an exemption for tribal governments. The TLSA, in its entirety, states that if signed into law, the act would amend "the National Labor Relations Act to provide that any Indian tribe or any enterprise or institution owned and operated by an Indian tribe and located on its lands is not considered an employer (thus excluding Indian tribes and such enterprises or institutions from coverage by the Act)" (p. 1). This would not prohibit unionization of tribal employees: it would give teeth to tribal governments' TRLOs, allowing tribal laws to govern labor relations with tribal employees on tribal land. Since 2015, policymakers have repeatedly brought the TLSA up for vote in Congress but so far it has failed to become law. An analysis of congressional testimony and policymakers' public comments on the TLSA sheds light on how federal Indian policies, which typically do not fall along partisan lines, and labor law, which is often marked by a partisan split between Democratic and Republicans, have combined to make the TLSA into a partisan wedge issue, unlikely to succeed in the foreseeable future.

On March 29, 2017, the House of Representative's Subcommittee on Health, Employment, Labor, and Pensions held its first and only hearing on the TLSA. Featuring testimonies by representatives from the Navajo Nation, Viejas Band of Kumeyaay Indians, and the National Congress of American Indians, as well as UNITE HERE (the union formed by the merger of HERE and the Union of Needletrades, Industrial, and Textile Employees), the hearing quickly delved into the question of whether the TLSA would protect tribal sovereignty at the expense of worker's rights to organize. The hearing's opening statement came from the committee's ranking member Gregorio Sablan, a delegate representing the Northern Mariana Islands. Sablan declared,

I am a Chamorro, one of the indigenous people of the Marianas, and fully appreciate the importance of tribal sovereignty for Native Americans. I also believe deeply in worker's rights to organize...Federal labor law and tribal sovereignty can comfortably co-exist at tribal casinos without stripping workers of their rights under the National Labor Relations Act...Tribal labor ordinances can be a workable option only if (1) they provide protections substantially equivalent to those afforded by the National Labor Relations Act, and (2) the NLRA exists as a backstop. (Subcommittee on Health, Employment, Labor, and Pensions, 2017, pp. 6-7)

As one of only a handful of Indigenous representatives ever elected to Congress, it would not be appropriate to characterize Sablan's call for a balance between tribal sovereignty and workers' rights as intended to advance settler colonialism. The United States recognizes over 570 tribal government, which means that if each is free to develop its own policies for labor relations, there could be a wide diversity of frameworks, ranging from supportive to hostile toward labor unions. For example, later during the hearing, Sablan entered into the record Section 3107 of the 2010 Blackfeet's TLRO, the Tribal Employment Rights Ordinance and Safety Enforcement Act of 2010, which reads "Unions are prohibited in the Blackfeet Indian reservation" (p. 57). Under San Manuel, the NLRA nullifies ordinances like this, at least when a tribe is operating a "commercial" enterprise like a casino. The TLSA would allow TRLOs like the Blackfeet's to ban all union organizing. It is understandable why supporters of organized labor would perceive the TLSA as a threat.

However, many state governments provide no framework for public employee unions, and some, like Virginia (Prohibition Against Collective Bargaining, 
2006), explicitly ban state employee unions. In his testimony, Viejas Band Chairman Robert Welch asserted that San Manuel created a double standard for tribal and state governments. Welch argued, "[Tribal governments] run just like federal, state, and local governments. The tribe should not be treated as...second class governments..." (Subcommittee on Health, Employment, Labor, and Pensions, 2017, p. 32). Cladoosby, president of the NCAI (the largest and oldest organization representing Native nations), echoed this point, reiterating that, "We just want to be treated as sovereigns, as other governments" (Hearing on H.R. 986, Tribal Labor Sovereignty Act, 2017, p. 42). Welch and Cladoosby were adamant that the TLSA is not about unionization, it is about sovereignty. If state governments can pass their own public sector labor relations laws, then why cannot tribal governments? While San Manuel found that that the NLRA should be applied to tribal casinos because gaming is not a "traditional" government activity, Cladoosby's testimony countered this, pointing out that "[there are] mega lotteries run by states across the nation. We're [tribal governments] not the only government that runs gaming" (Hearing on H.R. 986, Tribal Labor Sovereignty Act, 2017, p. 52). Likewise, where San Manuel cites the majority non-Native workforce as a reason for applying the NRLA, Cladoosby responded that, "... if you look at Las Vegas and Reno, where you have a lot of gaming, a lot of those employees come from outside of Las Vegas and Reno, and they can't vote there either. We just want to be treated the same as other governments" (Hearing on H.R. 986, Tribal Labor Sovereignty Act 2017, pp. 5657). Welch and Cladoosby's testimonies highlight that tribal governments are not the only governments that operate gambling and tribal casinos are not the only casinos with employees who cannot vote in the jurisdiction where they work.

The hearing laid bare the conflict exposed by San Manuel and the fault lines undermining the passage of the TLSA. Advocates for the TLSA argue it would establish parity between tribal and state governments. Just like state governments, some tribal governments may embrace public sector unions while others reject them. Opponents of the TLSA, like Sablan, do not see themselves as targeting tribal sovereignty or advancing settler colonialism. They view the TLSA as diminishing workers' ability to unionize. In assessing the continued impact of San Manuel, it is important to recognize the legitimate concerns of policymakers that value labor unions and worry the TLSA would undermine them. However, because support for labor unions often falls along partisan lines, the TLSA injected partisanship into the typically nonpartisan arena of federal Indian policies.

In January 2018, the TLSA passed the House of Representatives with bipartisan support in a 239-173 vote but in the Senate, it quickly became enmeshed in partisan politics. In April 2018, when TLSA first passed the Senate Committee of Indian Affairs, Senator Udall
(D-New Mexico), Vice Chair of the Committee, noted that, "Normally, our committee is very bipartisan...It was not so in this case today...I was not asked for input. Nothing about this bill was negotiated with me...It is shameful that this full body does not consider and resolve these and other important issues...And it is shameful that, when the Senate gives Indian Country its first shot in 10 years, Republicans closed the debate to prevent consideration of other pressing pieces of Indian Affairs legislation" (Udall, 2018, n.p.). Udall, who voted for the TLSA, voiced his frustration that the committee did not consider any other legislation, including bills that would have supported housing, education and healthcare on reservations. He accused his Republican colleagues of focusing only on the TLSA in order to make it a wedge issue, forcing Democrats to choose between supporting unions or tribes, without considering any other legislation that would support tribal sovereignty.

The day of the Senate vote, Senate Majority Leader Mitch McConnell framed his support in terms of tribal sovereignty when he tweeted, "This afternoon, the \#Senate will vote to advance legislation from Senator @JerryMoran that would bolster the proper sovereignty of American Indian tribes in the face of excessive federal regulation" (McConnell, 2018). As Sen. Udall noted, if Republicans truly supported tribal sovereignty, they would have considered other bills in addition to the NLRA. On April 16, when the NLRA came to a full Senate vote on a procedural motion to advance the bill, seven Democrats and one Independent joined 47 Republicans in voting "aye". With 55 votes, it failed to secure the 60 needed to advance (Schieber, 2018). The demise of the TLSA is not a direct result of policymakers intentionally pursing a settler colonial agenda. Instead, it failed because partisan politics turned tribal government labor relations into a wedge issue.

What does the TLSA tell us about tribal labor as a new arena for sovereignty? Federal Indian policy might typically be bipartisan, but it can intersect with other, much more partisan spheres. Senator Udall accused his Republican colleagues of only feigning interest in tribal sovereignty to force a vote that could make it appear that they have turned against labor organizations. The demise of the TLSA demonstrates that one of the greatest challenges to passing legislation that supports tribal sovereignty is that such legislation, while often bipartisan, can become mobilized in partisan disputes. In her influential book, Rich Indians: Native People and the Problem of Wealth in American History, Harmon (2010, p. 279) illustrates how "...controversies about Indian wealth have been dignified at times by meaningful discourse on important moral issues. Issues have included...the measures of fair economic opportunity and reward". While the achievements of tribal casinos are successes of tribal governments using the laws of the federal government to revitalize their sovereignty, they also draw attention to broader inequities in settler society, especially the unequal 
balance between employers and employees. Tribal governments do not deserve disproportionate attention for having this unbalance-it is embedded in the wider political-economy that was forced onto them. However, following Harmon's observation, it is a legitimate moral issue to question whether tribal casino employees, like any type of employee at any type of employer, have a fair chance at economic opportunity and reward. The decision of some tribal governments, like the Blackfeet, to prohibit government employees from engaging in union organization may be a blow to workers' rights, but the Blackfeet and other tribal governments have nowhere near the labor force of states like Virginia, that have similar prohibitions. If tribal governments are to have any meaningful parity with state and local governments, they would have the same capacity as other governments to regulate their employees' labor relations.

\section{Settler Colonialism and Tribal Gaming}

To be clear, tribal governments' opposition to San Manuel are by no means a typical labor versus management struggle, wherein an employer seeks to undermine employee attempts to organize. Kamper (2010) illustrates how many Native nations have long histories of supporting organized labor. The challenges posed by tribal casino labor relations is not a question of whether tribal casino operators want to stop their employees from organizing-many of them have actively encouraged it since the earliest days of tribal gaming (Gordon, 2010, p. 5) -the challenge is which labor relation laws should apply. Since San Manuel, federal courts have weighed in on the new precedent in cases that affirm it. Little River and Soaring Eagle, demonstrate that the structure of federal appeals courts, where a court of six judges are split into panels of three, with decisions from one panel binding later decisions, created a scenario where a majority of judges rejected San Manuel but were bound to apply it. The three judges on the Soaring Eagle panel had no choice but to displace tribal for federal law on tribal lands. In this way, we can see how settler colonialism can be advanced even by those who would reject it. Likewise, the failure of the TLSA is not necessarily the result of policymakers plotting to undermine tribal sovereignty, but the intersection of tribal casino labor relations with the partisan politics of organized labor.

On its face, tribal casino labor relations might seem to be an obscure and inconsequential corner of federal Indian policy. The D.C. Circuit Court may have been right that applying the NLRA would only have "some unpredictable, but probably modest, effect on tribal revenue and the displacement of legislative and executive authority that is secondary to a commercial undertaking" (San Manuel v NLRB, 2007 p. 8). After all, allowing employees to unionize under the NLRA and not TRLOs might impact employees' wages and benefits but so far none of the casinos involved in these cases have closed due to financial hardships caused by the NLRA. However, San Manuel and subsequent decisions may signal a broader shift towards greater constraints against tribal sovereignty. By throwing out the White Mountain Apache precedent, courts have signaled that successes of tribal gaming will result in reinterpreting laws to ensure that tribal governments remain on unequal footing with federal, state and local governments. In Little River, the 6th Circuit Court asserted that even though Tuscarora requires the Congress to have demonstrated intent for a law to apply to tribal governments, courts can infer Congress's intent without explicit evidence. With Pauma and the Supreme Court's refusal to hear its appeal, there currently is little opportunity for tribal governments to challenge San Manuel precedents through the courts. Now that the TLSA is mired in partisan fighting, it seems unlikely to mitigate the fallout of San Manuel.

While settler colonialism may be most visible in the diminished land-base of tribal governments, it is also at work when federal and state laws supplant tribal laws on tribal land, especially when these regulatory changes stem directly from tribal governments' achievements, like casino development. The cases described in this article and the failure of the TLSA demonstrate that settler colonialism continues to advance, even when the judges and policy makers responsible express support for tribal sovereignty. The San Manuel decision reveals that settler colonialism may have changed forms, but its underlying agenda remains the same. The double binds identified by Cattelino (2010) can come into play even by those who express support for tribal sovereignty. The structures of the United States political system require that challenging settler colonialism must entail more than changing the hearts and minds of individual judges and policymakers. Broader efforts of resistance are necessary, like the "politics of refusal" articulated by Audra Simpson (2014), where Native nations reject forms of recognition which force tribal governments into submission and interrupt narratives that purport the virtues of settler society. While the continued dominance of San Manuel signals a new wave of challenges, one factor remains clear: tribal governments will continue to learn from the structures of settler society in order to identify new strategies for strengthening their sovereignty.

\section{References}

Cattelino, J. (2010). The double bind of American Indian need-based sovereignty. Cultural Anthropology, 25(2), 235-262. https://doi.org/10.1111/j.1548-1360.2010.01058.x

Gordon, C. (2000). From hope to realization of dreams: Proposition 5 and California Indian gaming. In Indian Gaming: Who Wins? A. Mullis and D. Kamper, (Eds.). pp. 3-13. UCLA American Indian Studies Center.

Gordon, T. (2018). Cahuilla Nation activism and the tribal casino movement. University of Nevada Press.

Harmon, A. (2010). Rich Indians: Native people and the problem of wealth in American history. University of North Carolina Press. 
Hearing on H.R. 986, Tribal Labor Sovereignty Act (2017). Hearings Before The Subcommittee on Health, Employment, Labor, and Pensions. U.S. House of Representatives, One Hundred and Fifteenth Congress, First Session.

Kamper, D. (2010). The sovereignty of work: Tribal labor relations and self-determination at the Navajo Reservation. School for Advanced Research Press.

Lane, A. (1995). Return of the buffalo: The story behind America's Indian gaming explosion. Praeger.

McConnell, M. (2018). This afternoon, the \#Senate will vote to advance legislation from Senator @JerryMoran that would bolster the proper sovereignty of American Indian tribes in the face of excessive federal regulation. [Tweet]. https://twitter.com/senatemajldr/status/985980394280488961? ref_src=twsrc\%5Etfw\%7Ctwcamp\%5Etweetembed\%7Ctwterm \%5E985980394280488961\&ref_url=https\%3A\%2F\%2Fwww.ind ianz.com\%2FNews\%2F2018\%2F04\%2F17\%2Findian-countrycaught-in-drama-lawmakers.asp

Rose, N. (2006). Gambling and the law: Court rules tribal casino is merely a casino. Casino Enterprise Management, April, pp. 60-61.

Rossum, R. (2011). The Supreme Court and tribal gaming: California v. Cabazon Band of Mission Indians. University Press of Kansas.

Schieber, N. (2018). Senate Bill to Curtail Labor Rights on Tribal Land Falls Short. New York Times, April 17, Section B, Page 5.

Simspon, A. (2014). Mohawk Interruptus: Political life across the borders of settler states. Duke University Press.

Udall, T. (2018). Udall votes for Tribal Labor Sovereignty Act. [Press Release]. $\quad$ https://www.tomudall.senate.gov/news/pressreleases/udall-votes-for-tribal-labor-sovereignty-act

Wolfe P. (1999). Settler colonialism and the transformation of anthropology: The politics and poetics of an ethnographic event. Cassell.

\section{Legal Sources}

California v. Cabazon Band of Mission Indians, 480 U.S. 202 (1987)

Casino Paume v National Labor Relations Board No. 16-70397 ( $9^{\text {th }}$ Cir. 2018)

Federal Power Commission v. Tuscarora Indian Nation, 362 U.S. 99 (1960)

Fort Apache Timber Co., 226 N.L.R.B. 503 (N.L.R.B. 1976).

National Labor Relations Board v Little River, 359 NLRB 92 (6 $6^{\text {th }}$ Cir. 2015)

National Labor Relations Board v Soaring Eagle, 359 NLRB $92\left(6^{\text {th }}\right.$ Cir. 2015)

Prohibition Against Collective Bargaining. Code of Virginia Statute 40.1-57.2 (2006)

Seminole Tribe of Florida v Butterworth, 658 F.2d 310 (5th Cir. 1981)

San Manuel Indian Casino and Bingo 341 N.L.R.B. 1055 (N.L.R.B. 2004)

\section{Funding Statement}

In the past three years, the author received funding from the McKnight Foundation's Vibrant and Equitable Communities grant program and the Council for Independent College's Public Humanities for the Common Good grant program. These grants fund distinct projects researching Native American boarding schools and did not contribute to this article manuscript.

\section{Author Details}

Dr. Theodor P Gordon is a visiting assistant professor at the College of St. Benedict/St. John's University in St. Joseph, Minnesota, where he serves as director of the Initiative for Native Nation Revitalization. His research has received funding from the McKnight Foundation, the Sycuan Institute on Tribal Gaming, and the Council for Independent Colleges. His publications include Cahuilla Nation Activism and the Tribal Casino Movement (University of Nevada Press, 2018). He earned his PhD in Cultural Anthropology from the University of California, Riverside. 